Relations industrielles

Industrial Relations

\title{
The Labour Organizations
}

\section{The Canadian and Catholic Confederation of Labour}

\section{Alfred Charpentier}

Volume 4, numéro 1, septembre 1948

URI : https://id.erudit.org/iderudit/1023428ar

DOI : https://doi.org/10.7202/1023428ar

Aller au sommaire du numéro

\section{Éditeur(s)}

Département des relations industrielles de l’Université Laval

\section{ISSN}

0034-379X (imprimé)

1703-8138 (numérique)

Découvrir la revue

Citer cet article

Charpentier, A. (1948). The Labour Organizations: The Canadian and Catholic Confederation of Labour. Relations industrielles / Industrial Relations, 4(1), 3-5. https://doi.org/10.7202/1023428ar

Tous droits réservés @ Département des relations industrielles de l’Université Laval, 1948
Ce document est protégé par la loi sur le droit d'auteur. L'utilisation des services d'Érudit (y compris la reproduction) est assujettie à sa politique d'utilisation que vous pouvez consulter en ligne.

https://apropos.erudit.org/fr/usagers/politique-dutilisation/ 
THE LABOUR ORGANIZATIONS

Some time ago, we invited the three major central labour organizations in Canada - namely, the «Confédération des travailleurs catholiques du Canada» (the Canadian and Catholic Confederation of Labour), the Trades and Labor Congress and the Canadian Congress of Labor - to define in a short article the reasons standing for their distinct existence, their attitude towards the other organizations working in Canada for the same purpose and, finally, the main features of their policy. We want to thank Mr. Charpentier and Mr. Forsey for their sense of co-operation. Nothing have we heard from the Trades and Labor Congress.

\section{THE CANADIAN AND CATHOLIC CONFEDERATION OF LABOUR}

Alfred Charpentier

The «Confédération des travailleurs catholiques du Canada» (Canadian and Catholic Confederation of Labour) is a central labour organization made up of $16 \mathrm{Craft}$ Federations gathering 319 unions and 14 Central Councils; to the above organizations may be added 10 Craft Councils, each one consisting in Craft Unions of the same industry in particular districts, and 60 Unions not yet federated, but directly affiliated to the central organization. With all these affiliations, the C.T.C.C. can claim a total membership of 78,892 . Let it be said right now that the C.T.C.C. takes for its basis of organization the industrial level.

The Canadian and Catholic Confederation of Labour was founded in Hull, Quebec, in 1921. It gave a shape to the movement of Catholic trade-unionism which had slowly begun as soon as the year 1907, in Chicoutimi, Quebec. Instigated by the Catholic Hierarchy, this movement was in perfect correspondence with the urgent needs of the Quebec workers, definitely and mostly opposed to the American trade-unionism, which, after 40 years of steady efforts, had succeeded in organizing only $5 \%$ of the Quebec workers.

The structure of the C.T.C.C., up to now, has been developed almost entirely in the Catholic Province of Quebec; in effect, the C.T.C.C. claims only a few units in Ontario (Ottawa), and another centre in Moncton, New Brunswick. It is always possible that the Quebec Christian trade-unions spread in other Catholic districts in Canada, for the affiliation to the C.T.C.C. is not limited to French-Canadians. Not only Catholics - whatever be their nationality - can take part in it, but any worker ready to accept the social policy of the Church and the rule of Christian trade-unionism.

The C.T.C.C. has done much to increase the industrial security of the Quebec workers. Through it, was intensified the spreading of trade-unionism. During the 1930-1939 crisis, the C.T.C.C. constituted a strong rampart against the communist infiltration in the labour world; it caused the car. rying of a social legislation in direct line with the best principles of Christian Sociology. Thanks to its activity, the amazing extension of collective agreements was started - either the particular agreement or its extension to other parties. During the last twelve years, due to the work of the C.T. C.C., Quebec was the most tranquil Province in Canada, as far as strikes are concerned. Its purifying influence also has been felt in the industria] laws passed by the federal Parliament, especially during the six years of the Second World War.

The advanced legislation concerning collective bargaining and trade-union freedom - - for which the C.T.C.C. is mainly responsible - has brought about, among the whole teaching staff of Quebec, a strong movement of trade-unionism, in a parallel direction to an intense drive towards collective bargaining with school corporations. The rise of Catholic trade-unionism in Quebec has been an answer to their moral and social ideals.

The C.T.C.C. co-operates, as fas as possible, with neutral trade unions called «International 》 or «Canadian》 Unions. Collective labour agreements have been undersigned by both our unions and those organizations, in the following industries : barbering, building, footwear, printing, 
clothing, fur, furniture, building materials and plumbing.

At times, this co-operation with neutral unions also takes place in the legislative field, in Quebec, especially to protest against measures which constitute an attempt upon the workers' rights.

But during the last few years, the C.T.C.C. has been vigorously fighting against the tendency followed by neutral organizations to centralize in the hands of the federal government the whole of the new legislation on social security arisen from the war and from the crisis which immediately preceded it. On this matter, our national and Christian trade-unionism stands for a co-operative legislation between the federal and provincial governments, so that such a legislation be suitable to the economic, social and religious features of each Province. Everyone is aware of the very specific concept Quebec has on home life - its population being $80 \%$ Catholic.

The C.T.C.C. is, politically, an advocate of decentralization, because another of its aims is the establishing of professional corporations in the country, through industrial Councils which will soon be in operation in Quebec. Already, in the terms of the Law on juridical extension of collective agreements - which the C.T.C.C. alone fought for - $\rightarrow$ Parity Committees have taken shape in more than one hundred industries and crafts, and constitute so many embryos of the future professional corporations.

Neutral trade-unionism has a mechanistic concept of society; fort it, society is without a moral body; individuals are alone to face the government, there being nothing between the individuals and the State. This way of conceiving society leads to the exalting either of liberty, of the State or of the actual democracies.

In the neutral trade-unionism of this country, there is a mixture of those three concepts. In the aristocratic milieu of trade-unionism can still be found economic liberalism and class individualism. Many claim open allegiance to socialism, to collectivism. Finally, the great majority are dominated by a trend towards interventionism from the part of the actual democracies, that is, towards an attempt to counter-balance the rights of the individual and those of the State.

The Catholic trade-unionism does not suffer from this complex of three antagonistic attitudes towards liberalism, socialism and false demucracy. Why? Because its conception of society is different.

The C.T.C.C. stands for the organic concept of society, which then becomes a moral institution consisting in the reorganization of society by the co-operative and inter-dependant action of such natural groups as the family, the city and the profession, the State itself being constituted by the direct representatives of these groups.

To travel steadily in that line, the C.T.C.C. intends to remain at the same time a strictly professional and genuinely national power. So it refuses to endorse any political party. It condemns any match between the unions and the political parties as most baneful to the vital interrest of any trade-union movement in Canada. The C.T.C.C. has no link with any political party, but it always need the co-operation of the government party. It may fight the government on matters in which it refuses to co-operate, without, however, creating any tie with the official Opposition.

The C.T.C.C. considers it a sacred duty not to put its influence in the hands of any political party to help it gain power, which it is liable to lose at any time afterwards. A movement which showed such short-sightedness would have a hard time to regain its influence, if such a move did happen. History shows that the matches of trade-unionism with political parties have never ended the favor of the former; on the contrary, they constituted dreadful obstacles to the work, and in some countries, like France, they were absolutely fatal to the movement itself.

The alliance which took place, two years ago in Canada, between the Canadian Congress of Labour (C.C.L.) and the C.C.F. party may well become a disastrous experience in the history of trade-unionism in Canada. This mis-alliance constitutes as bad a deviation from its natural end as could be made by any trade-union movement, and the C.C.L. is responsible for it. The natural end of trade-unionism lies in organizing the profession inside the industry, over and above any political party, so that its mission be never interrupted, however violent may be the political fluctuations in our modern times.

To be always free from any political tie seems to be the wisest attitude to adopt if a movement wants to have authority and represent strongly in the benefit of Labour. This is free poli- 
tical action, and it is quite acceptable. This attitude, the C.T.C.C. intends to maintain.

The C.T.C.C. wants to remain a national power. It believes in the necessity of a fully autonomous Canadian trade-unionism, which can see for itself its own problems. It rejects as contrary to our national interest any subordination - either direct or indirect - to American trade-unionism.

Finally, it believes that trade-unionisin ought to be entirely national in its origin, its inspiration and its trend, if it wants to adapt its political, economic and social action to the best interest of the national economy, for the realization of the common good.

The Canadian and Catholic Confederation of Labour has gained for itself a reputation of uprightness. It is listened to with increasing interest by the governments. Its contribution to the Christian social restoration of the country is of the finest quality, and should not be underestimated.

\title{
THE CANADIAN CONGRESS OF LABOUR
}

\author{
Eugene Forsey
}

The Canadian Congress of Labour is the younger and slightly smaller of the two major central labour organizations in Canada. The Trades nad Labor Congress was founded in 1873, and by 1946 had about 356,000 members. The Canadian Congress of Labour was founded in 1940, and by 1946 had about 315,000 members.

The two Congresses differ not only in age and size but also in several much more important ways.

First, their basis of organization. 'The Trades and Labor Congress has some industrial unions, notably the International Ladies Garment Workers' Union and the Canadian Seamen's Union. But most of its membership is in craft unions. Plumbers are organized as plumbers, carpenters as carpenters, electricians as electricians, regardless of the particular job they work at.

This difference is very important. It is one of the main reasons why the C.C.L. grew from 70,000 to 315,000 members in six years, while the T.L.C. grew only from about 200,000 to 356,000 . The craft form of organization is not suited to modern mass production industry, where great corporations face large groups of semi-skilled or unskilled workers. Most of these workers have no craft. The attempt to organize them on a craft basis simply means that the big, powerful employer

Note of the Editors: This article was written a few months ago and no account has been made of changes which have occurred since. faces a scattering of small, weak unions, or none at all. Until a dozen years ago, the mass production industries in this country were almost wholly unorganized. The Dominion Department of Labour's Report on Labour Organization for 1935 does not even list the Automobile Workers, or the Iron, Steel and Tin Workers, the predecessors of the United Steelworkers, or the Woodworkers. As late as 1940, the Mine, Mill and Smelter Workers had only 176 members, the Packinghouse Workers' Organizing Committee only 221, the Rubber Workers 610, the Electrical, Radio and Machine Workers 637. By 1946, the Automobile Workers were the largest union in Canada, with 50,000 members; the Steelworkers came next, with 35,000 ; the Woodworkers were fourth, with 27,000; the Electrical, Radio and Machine Workers, with 22,000 and the Mine, Mill and Smelter Workers, with 21,675 , were practically tie with the Mine Workers and the Machinists for sixth place; the Packinghouse Workers had 17,000 members; the Rubber Workers had nearly 10,000 . It is hardly too much to say that in these industries industrial unionism wrought a revolution in a single decade, transforming them from a state of almost total lack of organization to one where practically all the important enterprises were under union agreements. In many instances, what were citadels of anti-unionism have become strongholds of unionism. The Trades and Labor Congress had met with little success in its occasional attempts to organize the unorganized, largely because its basis of organization was not suited to the task. The 